\title{
Properties of Spinach Ferredoxin in Anaerobic Urea Solution: A Comparison with the Native Protein
}

\author{
DAVID H. PETERING ${ }^{2}$ AND GRAHAM PALMER ${ }^{3}$ \\ Department of Biological Chemistry, Biophysics Research Division, Institute of Science and Technology, \\ Universily of Michigan, Ann Arbor, Michigan 48105 \\ Received June 19, 1970; accepted September 12, 1970
}

\begin{abstract}
The preparation of spinach ferredoxin by a modification of the method of Keresztes-Nagy and Margoliash which is particularly convenient for large-scale operation is described.

The optical, CD, and EPR spectra of this protein are studied in $5 \mathrm{M}$ urea as a function of ionic strength. At high ionic strength the various spectra are very similar to the native protein; at low ionic strength all three spectral parameters are greatly changed.

The reactivity of the protein with mercurial and iodoacetamide is compared. The very high reactivity of the former is rationalized by assuming an initial reaction with the sulfide moieties. Iodoacetamide reacts only with accompanying denaturation by an all-or-none mechanism. At most only one sulfhydryl is available for reaction, even in $5 \mathrm{~m}$ urca. This is consistent with the assumption that the mercaptides function as metal ligands.

A very sensitive instrument for the amperometric titration of SH groups is described.
\end{abstract}

Several reports have been published concerning the effect of urea upon the absorbance and circular dichroism spectra of ironsulfur proteins (1-4). Most of these studies have placed great weight on the interpretation of the CD spectra and thus are rather limited. To provide a more comprehensive analysis of the effect of urea we have compared five properties of spinach ferredoxin in the absence and presence of $5 \mathrm{~m}$ urea. Our results show that the interpretations of earlier experiments are equivocal and that the effect of urea is greatly complicated by a previously unsuspected effect of ionic strength.

${ }^{1}$ Supported by National Institutes of Health Research Grant GM 12176.

${ }^{2}$ NSF Predoctoral Fellow, present address: Department of Chemistry, Northwestern University, Evanston, Illinois.

${ }^{3}$ Career Development Awardee, GM-K3-21,213.

\section{MATERIALS AND METHODS}

Materials. Phenyl mercury acetate, organic analytical standard, was purchased from British Drug Houses, Ltd., iodoacetamide from Calbiochem, and urea, reagent grade, from Mallinckrodt. Before use, urea was incubated at $\mathrm{pH} 2$ for $30 \mathrm{~min}$ as a precaution against cyanate contamination and then recrystallized. Fresh spinach was obtained from the University of Michigan Food Service. All other reagents were reagent grade. Unless specified otherwise all Tris buffers were prepared from a stock solution of $0.7 \mathrm{M}$ Trischloride, $\mathrm{pH} 7.3\left(25^{\circ}\right)$. The DEAE-cellulose (Sleicher and Schuell, No. 70, Standard Type) and DE-52 (Whatman) were preequilibrated with 0.15 м Tris-chloride.

Preparation of ferredoxin. Spinach ferredoxin was prepared either according to the method of Tagawa and Arnon $(5,13)$ or by the following method which is based on the procedure of Keresztes-Nagy and Margoliash (6). Because we have found this latter method particularly satisfactory for the large-scale preparation of the protein, we describe it in detail. All steps are done in 
the cold room. Spinach leaves were blended in $500-\mathrm{g}$ batches with 1 liter of $\mathrm{H}_{2} \mathrm{O}, 10 \mathrm{ml}$ of $1 \mathrm{~m}$. Tris base, and $2 \mathrm{ml} 10^{-2} \mathrm{M}$ EDTA at high speed in a 1-gal Waring Blendor for $1 \mathrm{~min}$. Filtration through cheese cloth yielded a dark-green extract, $\mathrm{pH} 7.8$. To 20 liters of the aqueous extract was added $150 \mathrm{ml}$ of well-settled DEAE-cellulose slurry. After 1-hr of vigorous stirring, the resin was allowed to settle during a 2- to 3 -hr period (or overnight, if convenient). The supernatant fluid was collected by siphoning and was treated a second time with DEAE-cellulose. The darkgreen cellulose resin was easily isolated by centrifugation at $3000 \mathrm{rpm}$ for $10 \mathrm{~min}$ (International PR-6 centrifuge). It was washed batchwise with 0.007 м Tris buffer until the supernatant fluid was only faintly green; the washing is expedited if the DEAE-cellulose is centrifuged at low speeds as much of the green contamination is particulate, $500 \mathrm{rpm}$ for $1 \mathrm{~min}$ is convenient. The resin is packed into a column, washed with 2 liters of $0.15 \mathrm{M}$ Tris buffer, and then eluted with $0.15 \mathrm{M}$ Tris buffer containing $1 \mathrm{M} \mathrm{NaCl}$. This solution, about $10^{-4} \mathrm{M}$ in ferredoxin, was made $85 \%$ saturated in ammonium sulfate by the addition of $559 \mathrm{~g}$ of solid ammonium sulfate per liter of solution. A voluminous precipitate developed which was removed by centrifugation for $20 \mathrm{~min}$, at $10,000 \mathrm{rpm}$ in the SS-34 head of the Sorvall RC2 centrifuge. After dialysis of the supernatant fluid against two 10-vol portions of $0.01 \mathrm{~m}$ Tris buffer for a total of $8 \mathrm{hr}$, the ferredoxin solution was diluted 2 -fold with $\mathrm{H}_{2} \mathrm{O}$ and placed on a DEAE-cellulose column $(15 \times 4.5 \mathrm{~cm})$. Ferredoxin was eluted with $0.15 \mathrm{M}$ Tris- -16 м NaCl which left the bulk of the impurities bound to the column. At this point the solution has a value between $0.35-0.40$ for the ratio $(R)$ of the absorbance at $420 \mathrm{~m} \mu$ to that at $275 \mathrm{~m} \mu$. It is diluted 2-fold with water and batch-adsorbed onto a minimum quantity of DE-52. The darkbrown resin is packed into a column and quantitatively eluted with $0.15 \mathrm{~m}$ Tris $-1 \mathrm{M} \mathrm{NaCl}$ at a very slow flow rate. The concentrated eluate $(2-3 \times$ $\left.10^{-3} \mathrm{M}\right)$ is applied to a column $(4 \times 45 \mathrm{~cm})$ of Biogel P-60 which is developed with $0.15 \mathrm{~m}$ Tris buffer. The bulk of the red-brown eluate has a value of 0.48 or greater for $R$; lower values are found in both leading and tailing edges of the ferredoxin fraction. Fractions with $R>0.47$ are adsorbed and eluted from DE-52 as before and stored at $4^{\circ}$ in the eluting buffer; no deterioration of the protiein has been detected after several months when stored in this way. One hundred pounds of fresh spinach will vield about $1 \mathrm{~g}$ of protein by this procedure.

For the experiments described in this paper ferredoxin with ratios of $0.46-0.48$ was used rou- tinely. Standard disk-gel analysis $(8 \%$ gel $)$ of Inaterial of ratio, 0.475 , revealed a single, sharp band moving at the front. At higher gel concentrations, $(16,20$, and $24 \%$ ) which retard the mobility of ferredoxin, a faint trailing band was noted.

Amperometric titrimetry. Sulfhydryl and disulfide titers were determined amperometrically using the mercurial phenyl-mercury acetate, and a dropping mercury electrode. In place of the usual circuitry, in which current flow through the titration sample is measured directly with a galvanometer (7), the following circuit has been employed, in which $E_{1}$ provides a variable bucking emf against $i_{2} r$ (Fig. 1). When the voltmeter (NVM) is nulled, $E_{1}$ is equal to $i_{2} r$, in which $i_{2}$ is equal to $i_{d}$, the diffusion limited current due to the reduction of unbound mercurial at the electrode surface. The concentration of mercurial in the solution is proportional to $i_{d}$ and hence to $E_{1}$.

There are two advantages of this circuit design which contribute to the precision with which it measures $i_{d}$. First, there is only one standard visual task, the centering of the oscillatory deflection of the voltmeter about zero. Second, the nulling procedure can be done very carefully with the 10-turn micropot coupled with a 1000-division dial and a sensitive null voltmeter.

The sensitivity of this detection system is $10 \pm$ 2 divisions per $6 \mathrm{~m} \mu$ moles of phenyl mercury acetate in a $2-\mathrm{ml}$ vol. Figure 5 illustrates the reproducibility of ferredoxin titrations with this system. The Sargent manual polarograph provides a resolution of 1 scale division per $6 \mathrm{~m} \mu$ moles of mercurial and requires visual estimations of both extremities of the current oscillation, which continually change during the course of the titration.

Titrations were carried out anaerobically with $2 \mathrm{ml}$ of sample containing $30-300 \mathrm{~m} \mu$ moles of

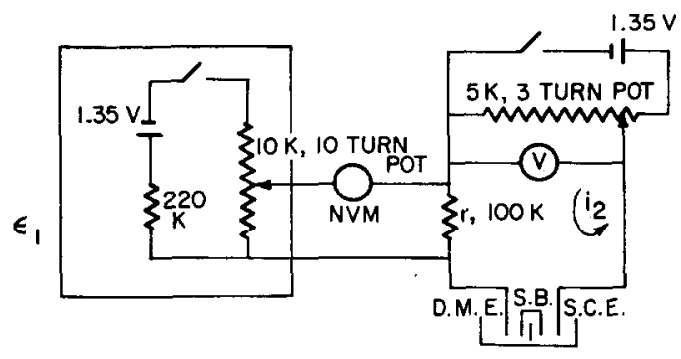

FIG. 1. Apparatus for amperometric titration. NVM $=$ Hewlett Packard Model 419A DC null voltmeter; $10 \mathrm{~K}, 10$ turn pot $=$ Borg $2201 \mathrm{~B}$ micropot; titration vessel, Sargent S-29405; dropping mercury electrode (DME), Sargent S-29419; Standard Calomel Electrode (SCE), Corning 476002. $\mathrm{SB}=$ Salt Bridge. 
sulfhydryl or disulfide and 0.4 mmole of $\mathrm{KCl}$. To titrate disulfide groups, $10 \mu \mathrm{l}$ of $1 \mathrm{M} \mathrm{Na}_{2} \mathrm{SO}_{3}$ was added prior to the titration. The mercurial selected for use was phenyl-mercury acetate, obtained as a microanalytical standard and employed in these titrations as the primary standard; it was delivered from a micrometer-controlled microburette. The voltage across the cell was set at $-500 \mathrm{mV}(8)$.

Analytical measurements. Absorbance spectra were obtained at room temperature with a Cary 15 spectrophotometer, and fixed-wavelength absorbance data taken on a Gilford modified DU spectrophotometer.

A Durrum-Jasco UV-5 scanning spectropolarimeter equipped for circular dichroism measurements was used to record CD spectra at room temperature. The spectra have been adjusted for baseline deviations. In the study of the effect of $\mathrm{NaCl}$ upon the absorbance and $\mathrm{CD}$ spectra of ferredoxin in anaerobic urea, an anaerobic cuvette with side arms was used. Salt additions were made from the sidearms or while the solution was under a nitrogen atmosphere. Spectra were taken 20-30 min after each salt addition. Concentration changes due to the evacuation procedure or to salt additions were corrected by the factor needed to adjust all of the optical spectra to the same absorbance at $420 \mathrm{~m} \mu$. This identity had been established in separate experiments. For these measurements 0.015 м Tris-Cl buffer, pH 7.5, was employed: this contributed little to solution ionic strength.

Electron paramagnetic resonance spectra were obtained with a Varian V-4500 spectrometer $(c f 9)$. Samples were reduced quickly in EPR tubes with a solution of sodium hydrosulfite and immediately frozen. Oxygen-free gases were obtained either by using Grade-6 helium (>99.999\% He) using a regulator with low inboard leakage or nitrogen which has been passed over hot copper turnings.

Alkylation with iodoacetamide in the absence of urea. Ferredoxin $\left(6.8 \times 10^{-4} \mathrm{M}\right)$ and iodoacetamide $(0.1 \mathrm{M})$ were incubated at room temperature in $0.15 \mathrm{M}$ Tris plus $1.0 \mathrm{M} \mathrm{NaCl}$. At given times, samples were removed from the reaction mixture and dialyzed at $4^{\circ}$ against $0.15 \mathrm{M}$ Tris-Cl, $\mathrm{pH} 7.9$. After the optical spectrum of the protein was taken, a sample suitable for arid hydrolysis was obtained by precipitation of protein with 5\% trichloroacetic acid, the protein collected by low-speed centrifugation and the precipitate washed with three 2-ml portions of $95 \%$ ethanol and then three 2-ml portions of ethyl ether and dried under vacuum. After hydrolysis in vacuo in $6 \mathrm{~N} \mathrm{HCl}$ at $110^{\circ}$ for $22 \mathrm{hr}$ the amino acid composition was determined on a Spinco $120 \mathrm{C}$ amino acid analyzer; the content of carboxymethylcysteine (CMC) was calculated as follows:

$$
\begin{aligned}
\frac{\text { moles } \mathrm{CMC}}{\text { moles } \mathrm{Fd}}=\frac{\text { moles CMC }}{\text { moles aspartate }} & \\
& \times \frac{13 \text { moles aspartate }}{1 \text { mole ferredoxin }}
\end{aligned}
$$

assuming 13 moles aspartate per mole of ferredoxin as determined by sequence analysis (10). The percentage of denaturation was calculated in two ways from the spectral data. One assumes that iron remains bound to the protein in the denatured state, so that extinction coefficients at $275 \mathrm{~m} \mu$ of denatured and native protein are the same; this is the situation with urea-oxygen bleached ferredoxin (11):

$$
\text { Percent age of denaturation }=\left(1-\frac{R_{\ell}}{R_{0}}\right)
$$$$
\times 100
$$

where $R_{0}=$ the initial value of $A_{420} / A_{275}$ and $R_{t}$ is the value of this ratio at the time the sample was obtained. The other assumes that iron is not bound in denatured ferredoxin and that the extinction coefficients of native and denatured proteins differ (11).

Percent age of denaturation $=$

$$
1-\left(\frac{1 /\left(\mathrm{R}_{0}-0.66\right)}{1 / \mathrm{R}_{t}-0.66}\right)=100 .
$$

Alkylation with iodoacetamide in $5 \mathrm{M}$ urea. One and five tenths milliliters of ferredoxin solution (3.4 $\mathrm{mm})$ was made anaerobic in the main body of a Thunberg tube and $0.59 \mathrm{~g}$ of solid urea was added. The evacuation and flushing procedure was continued and samples removed for optical spectra and amino acid analysis. A solution $(0.1 \mathrm{M})$ of iodoacetate was purged thoroughly with $\mathrm{N}_{2}$ and $0.46 \mathrm{ml}$ added to the urea-ferredoxin mixture. Samples $(50 \mu \mathrm{l})$ were subsequently removed at chosen intervals, diluted in $2.0 \mathrm{ml} 1 \mathrm{M} \mathrm{NaCl}$, the optical spectra taken, and then TCA added to 5\%. The protein precipitate was collected and washed and dried as above. The Thunberg tube was reevacuated and filled with $\mathrm{N}_{2}$ after each sample was withdrawn.

\section{RESULTS}

When spinach ferredoxin is dissolved in 5 м urea virtually no changes in absorbance occur at $420 \mathrm{~m} \mu$ provided oxygen is excluded (Fig. 2). However, on admission of oxygen there is a rapid disappearance of most of the visible color (1). Other oxidants produce the 


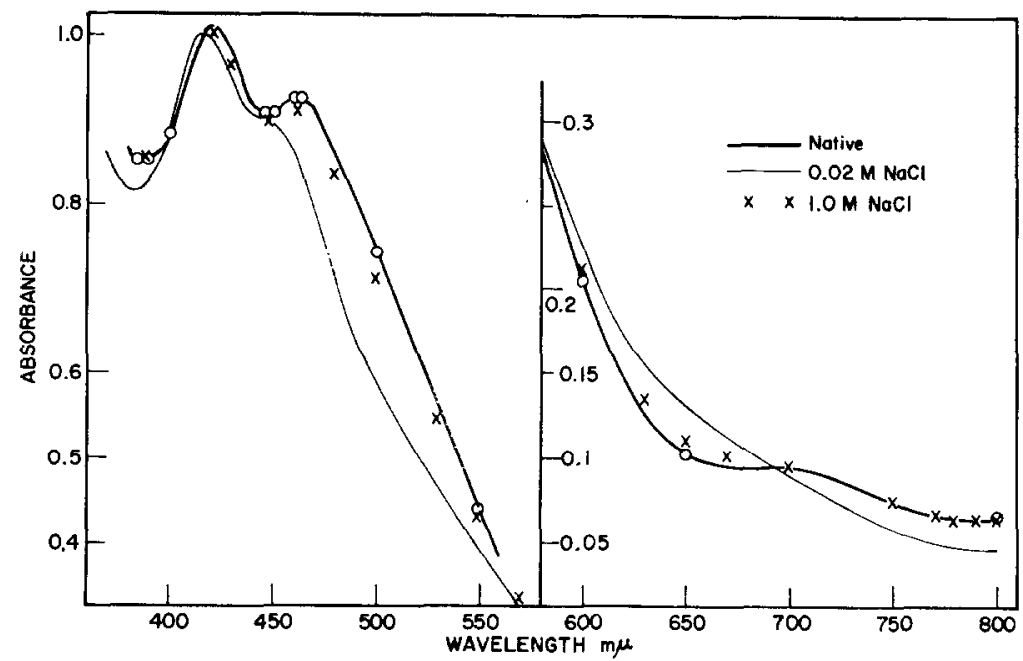

FIG. 2. Absorption spectrum of $1.05 \times 10^{-4} \mathrm{M}$ spinach ferredoxin (-O-), the protein in $5 \mathrm{~m}$ urea and $0.02 \mathrm{M} \mathrm{NaCl}(--)$ ) and after addition of solid $\mathrm{NaCl}$ to $1 \mathrm{M}(X)$ (cf. Fig. 3). The buffer was $0.015 \mathrm{M}$ Tris-chloride, $\mathrm{pH} 7.3$, and the temperature $23^{\circ}$. All data recorded anuerobically.

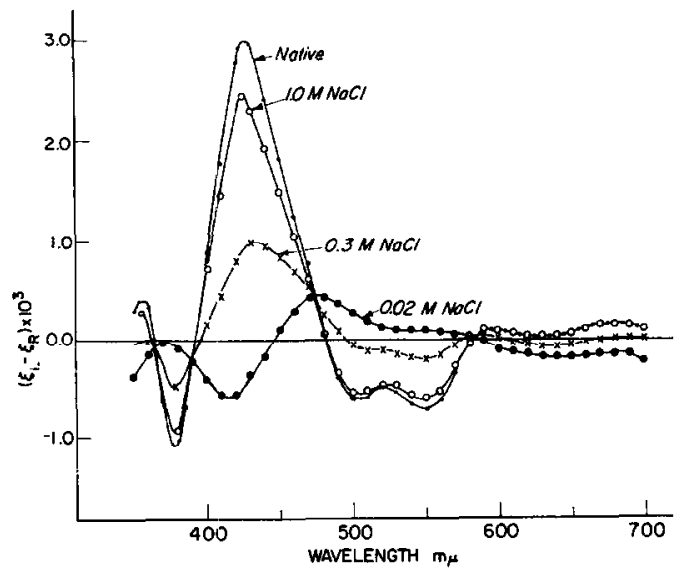

FIG. 3. CD spectrum of $1.05 \times 10^{-4} \mathrm{~m}$ spinach ferredoxin and the protein in $5 \mathrm{M}$ urea plus $0.02 \mathrm{M}$ sodium chloride. The spectra at higher salt concentrations were taken by the addition of solid sodium chloride from the side-arms of the Thunberg-type anaerobic cuvette. The buffer was $0.015 \mathrm{M}$ Tris-chloride, $\mathrm{pH} 7.3$, and the temperature $23^{\circ}$. All data were recorded anaerobically.

same effect and the protein product is substantially modified $(1,11)$. Even in $8 \mathrm{~m}$ urca ferredoxin shows no tendency to lose its visible color, but at these urea concentrations there are changes in several spectral properties of this protein, specifically in the optical, CD, and EPR spectra.

Circular dichroism spectra of oxidized spin- ach ferredoxin in $5 . M$ urea. The most striking effect of urea on the properties of ferredoxin is that the CD spectrum varies both qualitatively and quantitatively with the ionic strength of the solvent. Thus Fig. 3 shows that in $5 \mathrm{~m}$ urea and $1 \mathrm{~m}$ sodium chloride the CD spectrum of oxidized spinach ferredoxin is very similar to that of the urea-free protein. However, as the salt concentration is lowered the spectrum changes markedly and at $0.02 \mathrm{M}$ sodium chloride it is completely different from the spectrum in $1.0 \mathrm{M}$ sodium chloride. In particular, in going from 1 to $0.02 \mathrm{~m}$ sodium chloride the intense Cotton effect at $428 \mathrm{~m} \mu$ in high salt is replaced by a weak negative band at $420 \mathrm{~m} \mu$, the characteristic negative double trough at 500 and $550 \mathrm{~m} \mu$ is replaced by a small positive peak at $480 \mathrm{~m} \mu$ and a very weak broad positive absorption at $550 \mathrm{~m} \mu$, and the weak positive Cotton effects at wavelengths longer than $600 \mathrm{~m} \mu$ are replaced by weak negative absorptions. The low-salt spectrum is readily converted back to the high-salt form by addition of solid sodium chloride (Fig. 3). This salt effect is not ion specific; both potassium chloride and sodium sulfate can substitute for sodium chloride, though no quantitative data have been obtained. The intensity of the CD increased further with increasing salt and approached the intensity 
observed with the native protein. Figure 3 shows that there are four isosbestic points in this salt-induced transition at 584, 494, 390 , and $365 \mathrm{~m} \mu$, implying the existence of two, and only two, optically active species.

Optical spectra of spinach ferredoxin in $5 \mathrm{M}$ urea. Similar though less striking effects are seen in the optical spectra (Fig. 2). In high sodium chloride solution there is considerable similarity of the optical spectrum to that of the native protein particularly with regard to the presence of the peaks at 460 and $700 \mathrm{~m} \mu$ and the overall increase in absorption in the 450 - to $500-\mathrm{m} \mu$ region. By contrast the spectrum in low salt has its maximum at 417 , a poorly defined shoulder at $450 \mathrm{~m} \mu$, and generally decreased absorption out to $550 \mathrm{~m} \mu$. There is a small increase in absorption in the region $580-680 \mathrm{~m} \mu$ in low salt. Again, these differences can be reversed by the addition of sodium chloride.

EPR spectra of reduced spinach ferredoxin in 5 M urea. Oxidized spinach ferredoxin shows no EPR from 0-5 k-gauss $(\mathrm{kG})$ in the absence of urea or in urea solution as high as $7.5 \mathrm{M}$ when the solvent is $0.015 \mathrm{M}$ Tris, $\mathrm{pH} 7.3$, containing $1 \mathrm{~m} \mathrm{NaCl}$. The reduced protein shows the $g=1.94 \mathrm{EPR}$ signal and no other resonance between 0-5 kG (Fig. 4). The intensity of the resonance in $5 \mathrm{M}$ urea is the same as that in the absence of urea; above $5 \mathrm{M}$, however, the intensity decreases and by $7.5 \mathrm{~m}$ urea only about $50 \%$ of $\max$ imum intensity is observed. In these experiments ferredoxin, buffer, and concentrated urea are mixed together aerobically, transferred rapidly to an EPR tube containing a solution of dithionite, the contents of the tube mixed, incubated for 30 sec, and frozen. Thus the decrease in intensity above $5 \mathrm{M}$ urea may be due to the oxygen sensitivity of the protein which is particularly marked at the high urea concentration. There are small changes in the EPR spectra on increasing the urea concentration; $g_{z}$ and $g_{y}$ move to higher magnetic fields by 2 and $4 \mathrm{G}$, respectively, and $g_{x}$ moves downfield by some $6 \mathrm{G}$ as the urea concentration is increased from 0 to $7.5 \mathrm{~m}$. These variations in $g$ value may be only apparent, however, for there are concomitant changes in the linewidths of the spectra over the same range of urea concentration. Thus the halfwidth at $g_{z}$ increases

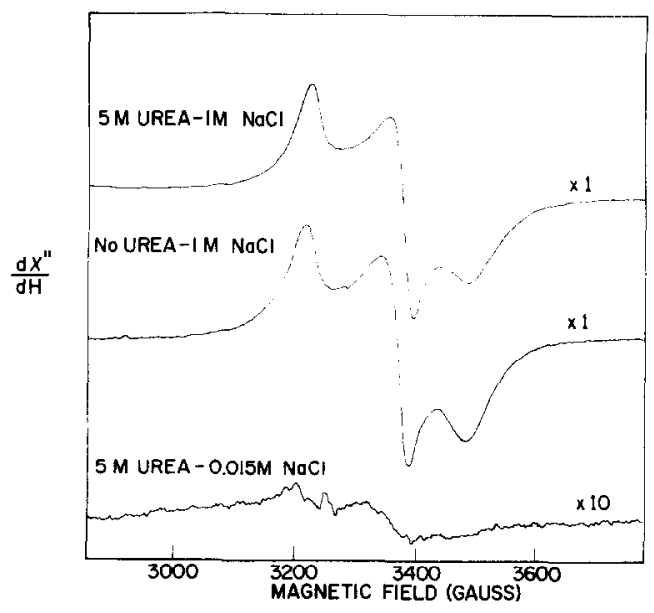

FIG. 4. EPR spectra of reduced spinach ferredoxin $(1.5 \mathrm{~mm}$ ) in $5 \mathrm{~m}$ urea-1 $\mathrm{M} \mathrm{NaCl}$ (top), no urea-0.015 м NaCl (middle), and $5 \mathrm{~m}$ urea-0.015 $\mathrm{M}$ $\mathrm{NaCl}$ (bottom). In this experiment a sample of ferredoxin was dialyzed for $5 \mathrm{hr}$ vs $0.015 \mathrm{M}$ Trischloride plus $0.02 \mathrm{M} \mathrm{NaCl}$, and a sample $(0.4 \mathrm{ml})$ placed in one side-arm of a two side-arm Thunberg tube. Urea $(0.16 \mathrm{~g})$ was placed in the second sidearm, the vessel rendered anaerobic and left under nitrogen gas. The ferredoxin and urea were mixed and the solution was incubated at room temperature for $30 \mathrm{~min}$. A swelling factor of 1.3 is assumed (11). The sample in high salt was prepared by adding the requisite amount of solid $\mathrm{NaCl}$ to the ferredoxin solution before placing in the Thunberg tube. The vessel was opened, a portion of the ferredoxin solution transferred aerobicully to an EPR tube and then reduced by the addition of $20 \mu \mathrm{l}$ of $0.5 \mathrm{M}$ solution of dithionite (in $0.5 \mathrm{M}$ borate, $\mathrm{pH} 9.0$ ). EPR conditions: microwave frequency, $9.2 \mathrm{GHz}$; microwave power $=3 \mathrm{~mW}$; modulation amplitude, $9 \mathrm{G}$; scan rate, $200 \mathrm{G} / \mathrm{min}$; time constant, 1 sec, temp. $=79^{\circ} \mathrm{K}$.

from 19 to $21 \mathrm{G}$, that at $g_{y}$ from 20 to $25 \mathrm{G}$, while no significant change in the experimental linewidth is observed at $g_{x}$.

When the protein is reduced in low $(0.02 \mathrm{M})$ sodium chloride and $5 \mathrm{M}$ urea the color changes instantly from red-brown to pale green-brown, and this reduced state shows no EPR even at instrumental settings where the protein in high salt gives very large signals (Fig. 4). Protein in low salt in the absence of urea shows full EPR intensity and no unusual color changes.

Reactivity with sulfhydryl agents. Native ferredoxin reacts rapidly and completely with mercurial reagents $(1,11,12)$. By am- 


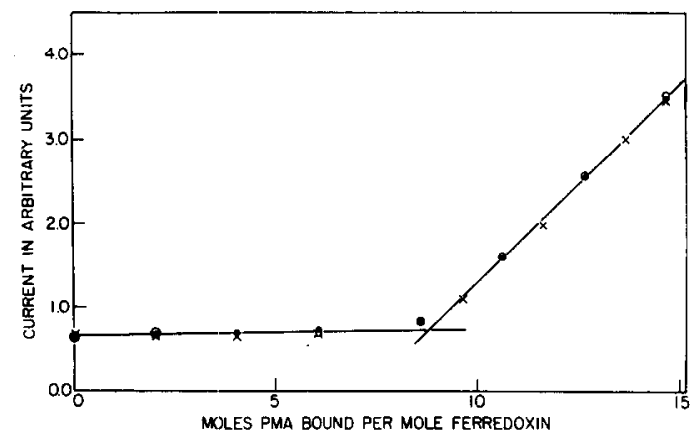

FIG. 5. Amperometric titration of spinach ferredoxin (triple analyses). For details see experimental section.

perometric titration a mercurial titer of $8.8 \pm 0.2$ for eight titrations on three preparations of protein was determined (Fig. 5). In 5 м urea, two samples preincubated anacrobically for $1 \mathrm{hr}$ in the titration vessel gave values of 8.3 and 8.8 moles of mercurial. The excellent agreement between the three sets of data (Fig. 5) provides good evidence for the high precision of the amperometric method. The labile sulfide content of protein so incubated was 1.8 ; this compared to a value of 2.0 for the native protein.

A second sulfhydryl agent, iodoacetamide, reacts very slowly with native ferredoxin, but more rapidly in the presence of urea (Table I, Fig. 6). Over 48 hr native ferredoxin is only partially bleached in ca 100 -fold molar excess of the alkylating agent, and the extent of alkylation of sulfhydryl groups agrees satisfactorily with the percentage of bleaching assuming the thiol groups of each denatured protein molecule react completely with iodoacetamide. Certainly no rapid alkylation of one or more sulfhydryls which is undetected by absorbance measurement occurs.

The reaction in $5 \mathrm{~m}$ urea is much more rapid but once more is accompanied by loss of the visible spectrum of the protein (Fig. 6). The kinetics of alkylation appear simple and there is no suggestion of any differential reactivity from the alkylation data. However, the parallel spectrophotometric measurements show relatively little change in absorbance during the formation of the first mole of carboxymethyl-cysteine, suggesting that there may be one sulfhydryl group which can be alkylated without significant perturbation of the visible spectrum. At longer reaction times the absorbance is an unreliable indication of denaturation because of the production of iodine. So at the end of $5 \mathrm{hr}$ the reaction mixture was diluted with $20 \mathrm{ml}$ of $\mathrm{H}_{2} \mathrm{O}$ and applied to a $1 \times 2-\mathrm{cm}$ DE52 column. The column was washed with

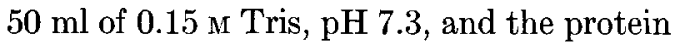
was eluted with the same buffer containing 1 m sodium chloride. The optical spectrum of the colored eluate was identical to native spinach ferredoxin from $800-360 \mathrm{~m} \mu$. At shorter wavelengths the absorbance increased rapidly due to the presence of carboxymethylated apoprotein. The CD spectrum of the eluate was identical with native spinach ferredoxin from $700-300 \mathrm{~m} \mu$. The ratio of the absorbance at $420 \mathrm{~m} \mu$ to that at $275 \mathrm{~m} \mu$ was 0.12 .

The percentage of denaturation calculated as described in the experimental section is

'TABLE' I ${ }^{a}$

Alkylation of Native Ferredoxin

\begin{tabular}{|c|c|c|c|c|c|c|}
\hline \multirow{2}{*}{ Time $(\mathrm{hr})$} & \multirow{2}{*}{$R$} & \multicolumn{2}{|c|}{ Percent denaturation ${ }^{b}$} & \multicolumn{2}{|c|}{$\begin{array}{l}\text { Carboxymethyl cysteine } \\
\text { expected (mole/mole Fd) }\end{array}$} & \multirow{2}{*}{$\begin{array}{l}\text { Carboxymethyl } \\
\text { cysteine found } \\
\text { (mole/mole Fd) }\end{array}$} \\
\hline & & A & $B$ & A & B & \\
\hline 0 & 0.475 & 0 & 0 & 0 & 0 & 0 \\
\hline 12 & - & $\cdots$ & $\cdots$ & - & - & 0.5 \\
\hline 24 & 0.427 & 16 & 10 & 0.8 & 0.5 & 0.67 \\
\hline 48 & 0.32 & 44 & 33 & 2.3 & 1.65 & 1.79 \\
\hline
\end{tabular}

a For details see experimental section.

${ }^{b}$ Calculated according to Eqs. 1 (A) and 2 (B).

${ }^{c}$ Calculated from percentage of denaturation assuming 5 moles carboxymethyl-cysteine per mole protein. 


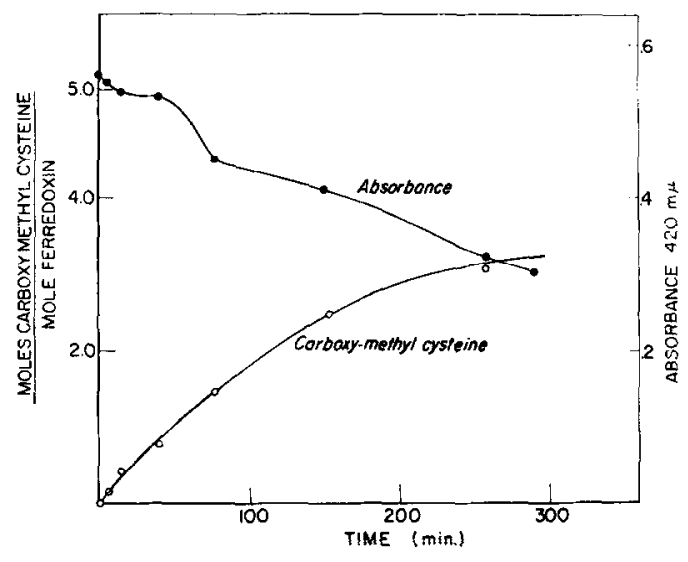

FIg. 6. Alkylation of spinach ferredoxin in $5 \mathrm{M}$ urea as monitored by the decrease in absorbance at $420 \mathrm{~m} \mu$ (๑) and formation of carboxymethylcysteine $(O)$. For details see experimental section.

$75-81 \%$ corresponding to $3.75-4.05$ moles carboxymethyl-cysteine formed. Extrapolation of the data of Fig. 6 to 300 min gives a value of 3.6 moles carboxymethyl-cysteine.

\section{DISCUSSION}

The spectral comparison of native ferredoxin with the protein in anaerobic, $5 \mathrm{M}$ urea solution demonstrates that at least in high ionic strength the chromophore and EPR center are only marginally perturbed by the presence of the potential denaturant. Thus, the details of both the optical and CD spectra are preserved while the changes in the EPR spectra are so small that clearly any modification of the fundamental geometry of the site is marginal.

The absorbance and EPR spectra monitor the integrity of the iron site but the CD spectrum is, in principle, sensitive both to details of the geometry of the site and the local conformation of the protein in the environment of the site. Thus, Padmanabham and Kimura have suggested that for both adrenodoxin and spinach ferredoxin the optical activity of the metal site may result from an asymmetry imposed upon an intrinsically symmetric chromophore by the protein structure (3). They based their original proposal upon the observation that during the aerobic denaturation of adrenodoxin the CD spectrum has been essentially destroyed under conditions which preserve most of the 414-m $\mu$ absorbance of the protein. Further experiments (4) revealed that the first step was a very rapid conversion of the protein to a species with spectral properties similar to those which we see in the presence of urea anaerobically when the ionic strength is low (Fig. 3), i.e. because these workers confined their experiments to low ionic strength, they overlooked the dramatic effect of salt concentration on these phenomena. This species is characterized by an optical spectrum modified to the extent that the $460 \mathrm{~m} \mu$ peak is lost and a significant amount of absorption in the 400- to $550-\mathrm{m} \mu$ region has disappeared, and a CD spectrum that is completely different from the native protein being only feebly optically active and having its own characteristic set of optically active transitions; as we have shown (Fig. 3), this transition is reversible. This may be interpreted to mean that the constitution of the active center has been preserved in the high-low salt transition even though the conformation of this site may have changed significantly. If the sample is now made aerobic, this new species slowly disappears as judged by the loss of the residual optical activity and a substantial decrease in the visible absorbance of the sample $(1,4,11)$.

Padmanabham and Kimura $(3,4)$ used these data to claim that the origin of the optical activity is extrinsic. We believe this is an arbitrary interpretation of the results.

The initial species formed in these experiments and the species we observe at low ionic strength are clearly different from the native protein by scveral criteria. First, the optical spectra are not identical. To workers not familiar with this area the differences in optical spectra may seem small. However, it should be pointed out that optical spectra similar to the low salt species are readily produced in model systems (14) and artificial nonheme iron proteins (15) which are obtained by the judicious mixing of iron, sulfide, and thiol donor.

Second, the disappearance of the natural CD spectrum is just as readily inierpreted as being due to a modification of the site. Indeed, if the activity were arising from an asymmetry imposed by the protein, would one expect the CD spectra of proteins as diverse as spinach ferredoxin (16), adreno- 
doxin (16), Azotobacter protein III (17), and xanthine oxidase (18) to give CD spectra which are so strikingly similar? It must be emphasized that the high and low salt species are reasonably stable under anaerobic conditions but that, in the presence of oxygen, both species denature by oxygen (11). Thus, the proposal by Padmanabhan and Kimura (4) of a complex sequence of denaturation due to urea is unacceptable because it ignores both the salt-dependent transition between optically different species and the sensitivity of these species to oxygen.

Thirdly, the reduced protein in low salt gives no EPR spectrum even when frozen within seconds after reduction whereas both the urea-free protein in low salt and the urea-containing protein in high salt give full EPR signals under these conditions.

Clearly these arguments do not eliminate the possibility that the optical activity is of extrinsic origin. For instance it could be argued that the absence of an EPR signal is a consequence of a very rapid disintegration of the active center on reduction. Such a reaction is not ruled out by our data, but we see less than $1 \%$ of the anticipated EPR even when the sample was frozen in $c a 10$ sec. A more satisfying interpretation of all the available data is that the initial species formed in strong urea under conditions of low ionic strength is a modified form of the active center with a different optical spectrum, intrinsically lower optical activity and, on reduction, no EPR signal. This proposal is similar to that proposed by Garbett et al. who first observed that $8 \mathrm{~m}$ urea converts the CD spectrum of spinach ferredoxin to a completely new form while only mildly perturbing the optical spectrum (2). They thus proposed that these differential affects were due to an increase in the structural symmetry of the chromophore by changes in protein structure which left the site intact. This effect of ionic strength on the properties of this protein are most easily explained as a salt-induced conformational change in the protein, a process which might be detected by changes in the ultraviolet optical activity of the protein.

However, the extremely high absorbance of the urea solution in the ultraviolet will make this extremely difficult to demonstrate experimentally by direct CD measurements, while the indirect ORD method is not applicable because of the large changes in optical activity associated with the visible chromophore.

The mercurial phenylmercuric acetate reacts rapidly and quantitatively with spinach ferredoxin both in the absence and presence of urea. The value of 9 moles of mercurial bound/mole of protein is, of course, anticipated on the basis of the cysteine and sulfide content of this protein on the assumption that each mercaptide binds one mercurial and each sulfide two. It should be emphasized that results obtained by the amperometric method give an absolute value for the mercurial titer. Previous analyses (e.g. 5) have relied on the disappearance of the absorption at $420 \mathrm{~m} \mu$ after addition of mercurial, a procedure which need only measure the number of mercurial sites present at the active center or on the uv-monitored formation of mercaptide bonds, a method which is unreliable in proteins with nonprotein chromophores (21). The fact that both methods of analysis give the same result implies either that all of the mercurial are indeed at the active center of the protein or that the denaturation produced by mercurial occurs in an all-or-none manner; 5 m urea has essentially no effect on the titration. The excellent precision of the amperometric method can be judged from the data of Fig. 5 .

By contrast, iodoacetamide reacts very sluggishly with the native protein though considerably faster in the presence of urea. This difference between the mercurial and iodoacetamide may well be a reflection of the differences in reactivity of these two reagents, for although both reagents react with thiol groups, mercurial binds sulfide much more avidly than does the alkylating agent. In this interpretation the sulfhydryl groups of the protein are not available for reaction, hence the ineffectiveness of iodoacetamide. However, mercurial can attack the labile sulfide of the site leading to an uncovering of the thiol groups as the site disintegrates.

This proposal is supported by the chemical data on the carboxymethylation of the protein, for it is clear (Table I, Fig. 6) that with both native and urea-perturbed ferre- 
doxin iodoacetamide is only able to alkylate sulfhydryl groups when there is concurrent site destruction. This appears to proceed in an all-or-none manner as judged by (1) the monophasic nature of the reaction with iodoacetamide, (2) the observation that after $75-80 \%$ of the reaction has proceeded, the residual visible and CD spectra were those of the native protein. Thus, apart from the possibility that the first mole of iodoacetamide might react without destruction of the active center there is no evidence for any selective reaction of this reagent with the protein.

For whatever reason it appears that at least four and possibly all five of the thiol groups are effectively buried within the protein and that at most only one is sufficiently uncoupled from the chromophore, since it may be alkylated without complete degradation of the protein. The identification of this residue would provide an important piece of information in attempts to characterize the active center of the protein.

It is relevant that a similar conclusion was also reached from attempts to alkylate rubredoxin in the presence of denaturant (19); with this protein recent X-ray work (20) has demonstrated that the mercaptide moieties function as ligands for the iron atom and one might extrapolate these findings to spinach ferredoxin by concluding that in this protein also, four, and possibly five, of the cysteine residues function as ligands to the iron atoms as has been previously proposed (22).

\section{REFERENCES}

1. Petering, D. H., and Palmer, G., Fed. Proc. 26, Abstr. 2651. (1967).

2. Garbett, K., Gillard, R. D., Knowles, P. F., AND Strangroom, J. E., Nature London 215, 824 (1967).

3. Padmanabhan, R., and Kimura, T., Biochem. Biophys. Res. Commun. 37, 363 (1962).
4. Padmanabhan, R., and Kimura, T., J. Biol. Chem. 245, 2469 (1970).

5. Tagawa, K., and Arnon, D. I., Biochim. Biophys. Acta 153, 602 (1968).

6. Keresztes-Nagy, S., and Margoliash, E., J. Biol. Chem. 241, 5955 (1966).

7. Meites, L., and Thomas, H. C., "Advanced Analytical Chemistry," p. 173. MeGrawHill, New York (1958).

8. Benesch, R., and Benesch, R. E., J. Amer. Chem. Soc. 73, 3391 (1951).

9. Palmer, G., In "Methods in Enzymology" (R. Estabrook and M. Pullman eds.), Vol. 10, p. 365. Academic Press, New York (1967).

10. Matsubara, H., Sasaki, R. M., and Chain, R. K., Proc. Nat. Acad. Sci. U.S.A. 57, 439 (1967).

11. Petering, D. H., Fee, J. A., and Palmer, G., J. Biol. Chem., Submitted.

12. Fry, K. T., And San Pietro, A., In "Photosynthetic Mechanisms of Plants," Publ. 1145. p. 252. Nat. Acad. Sci., Nat. Res. Council, Washington, D. C., 1963.

13. Tagawa, K., and Arnon, D. I., Nature 95, 537 (1962).

14. Yang, C. S., and Huennehens, F. M., Biochem. Biophys. Res. Commun. 35, 634 (1969).

15. McCarthy, K., and Lovenberg, W., J. Biol. Chem. 243, 6436 (1968).

16. Palmer, G., Brintzinger, H., and Estaвкоок, R. W., Biochemistry 6, 1658 (1967).

17. Dervatanian, D. V., Shethna, Y. I., and Beinert, H., Biochim. Biophys. Acta 194, 548 (1969).

18. Palmer, G., and Massey, V., J. Biol. Chem. 244, 2614 (1969).

19. Bachmayer, H., Piette, L. H., Yasanobu, K. T., and Whitely, H. R., Proc. Nat. Acad. Sci. U.S.A. 57, 122 (1967).

20. Herriotw, J. R., Sreker, L. C., and Jensen, L. H., AND Lovenberg, J. Mol. Biol., 50, 391 (1970).

21. Palmer, G., And Massey, V., Biochim. Biophys. Acta 58, 349 (1962).

22. Brintzinger, H., Palmer, G., and Sands, R. H., Proc. Nat. Acad. Sci. U.S.A. 55, 397 (1966). 